\title{
POLA KEMAMPUAN KOGNITIF DAN KETERAMPILAN BERPIKIR KREATIF PADA KONSEP PERUBAHAN LINGKUNGAN ANTARA SISWA LAKI-LAKI DAN PEREMPUAN DI SMA NEGERI 2 MRANGGEN
}

\author{
Mira Esti Kusumaningrum ${ }^{1}$, Joko Siswanto ${ }^{2}$, Fenny Roshayanti ${ }^{3}$ \\ ${ }^{1}$ Universitas PGRI Semarang, Kota Semarang, 50125, Indonesia \\ Email: esti.mira13@gmail.com \\ ${ }^{2}$ Pendidikan IPA, Pascasarjana, Universitas PGRI Semarang, Kota Semarang, 50125, Indonesia \\ Email: ${ }^{2}$ jokosiswanto@ upgris.ac.id; ${ }^{3}$ fennyrosh@gmail.com
}

Diajukan: 21 Agustus 2020; Diterima: 20 September 2020; Diterbitkan: 31 Oktober 2020

\begin{abstract}
Abstrak: Penelitian ini bertujuan untuk mengetahui pola kemampuan kognitif dan keterampilan berpikir kreatif antara siswa laki-laki dan perempuan di SMA Negeri 2 Mranggen. Penelitian ini termasuk dalam penelitian non eksperimen. Populasi penelitian adalah siswa kelas XI yang terdiri dari 9 kelas. Teknik sampling menggunakan stratified proportional random sampling, menggunakan rumus Slovin dengan taraf signifikan 10\%, sehingga diperoleh 76 siswa dari 324 siswa, masing-masing 38 siswa untuk laki-laki dan perempuan. Teknik pengumpulan data dalam penelitian ini berupa tes kemampuan koginitf dan keterampilan berpikir kreatif dalam bentuk soal pilihan ganda dan uraian pada materi perubahan lingkungan. Instrument yang digunakan berupa soal pilihan ganda yang memuat C1-C6 untuk kemampuan kognitif dan aspek berpikir kreatif untuk soal uraian. Data yang terkumpul kemudian dianalisis menggunakan anlisis deskriptif kuantitatif dan t-test independent, dengan taraf signifikansi 0,05 . Hasil penelitian menunjukkan t-hitung sebesar -1,067 dan t-tabel dengan signifikanasi $(\alpha) 5 \%$ sebesar 1,922 untuk kemampuan kognitif. Sementara itu, keterampilan berpikir kreatif diperoleh bahwa t-hitung sebesar -3,088 dan t-tabel dengan signifikanasi ( $\alpha$ ) 5\% sebesar 1,922. Hasil perhitungan keduanya menunjukkan bahwa H0 gagal ditolak yang berarti tidak ada perbedaan nyata antara keterampilan berpikir kreatif siswa laki-laki dengan siswa perempuan.
\end{abstract}

Kata kunci: Kemampuan kognitif, keterampilan berpikir kreatif, laki-laki, perempuan

\begin{abstract}
This study aims to determine the pattern of cognitive abilities and creative thinking skills between male and female students at SMA Negeri 2 Mranggen. This research is included in non-experimental research. The research population is class XI students which consist of 9 classes. The sampling technique used stratified proportional random sampling, using the Slovin formula with a significant level of 10\%, in order to obtain 76 students from 324 students, 38 students each for male and female. Data collection techniques in this study were in the form of tests of cognitive abilities and creative thinking skills in the form of multiple choice questions and descriptions of environmental change material. The instrument used is in the form of multiple choice questions containing C1-C6 for cognitive abilities and creative thinking aspects for description questions. The collected data was then analyzed using quantitative descriptive analysis and independent $t$-test, with a significance level of 0.05 . The results showed that the $t$-count was -1.067 and the $t$-table with a significance $(\alpha)$ of $5 \%$ was 1.922 for cognitive abilities. Meanwhile, creative thinking skills obtained that the t-count is -3.088 and the t-table with a significance $(\alpha) 5 \%$ is 1.922 . The results of both calculations show that $\mathrm{HO}$ failed to be rejected, which means there is no real difference between the creative thinking skills of male students and female students.
\end{abstract}

Keywords: Cognitive ability, creative thinking skills, male, female

\section{Pendahuluan}

Perkembangan ilmu pengetahuan dan teknologi di abad 21 telah mengubah wajah peradaban dunia dan mengantarkan kita pada satu era Revolusi Industri yang keempat atau lebih dikenal dengan 4.0. Selain itu, era ini merupakan fase revolusi teknologi yang mampu mengubah cara beraktifitas manusia dalam skala, ruang lingkup, kompleksitas, dan transformasi dari pengalaman hidup sebelumnya. Manusia bahkan akan hidup dalam ketidakpastian (uncertainty) global (Zubaidah, 2018).

Dalam rangka menjawab tantangan era tersebut diperlukan persiapan sumber daya 
manusia yang mampu berkecakapan sesuai kebutuhan abad 21. Menurut Griffin \& Care (2018) keterampilan dan sikap abad 21 digolongkan sebagai ways to thinking (knowledge, critical and creative thinking), ways to learning (literacy and softskills), dan ways to learning with other (personal, social, and civic responsibilities). Pada umumnya dikenal dengan kompetensi $4 \mathrm{C}$ yang terdiri atas ; mengidentifikasi keterampilan berpikir kritis (Critical Thinking Skills) ; keterampilan berpikir kreatif (Creative Thinking Skills) ; keterampilan komunikasi (Communication skills) ; dan keterampilan kolaborasi (Collaboration skills).

Kompetensi 4C dapat dikembangkan dalam pembelajaran melalui pembelajaran yang berbasis masalah. Kemampuan berpikir yang menjadi bagian dari komptensi 4C termasuk ke dalam kemampuan kognitif, karena merupakan kemampuan dasar untuk berpikir. Ibda (2015) menyatakan bahwa Piaget mengajukan teori perkembangan kognitif anak yang melibatkan proses-proses penting, yaitu skema, asimilasi, akomodasi, organisasi, dan ekuilibrasi. Dalam teorinya, perkembangan kognitif terjadi dalam empat tahap, yaitu tahap sensorimotor, pra-operasional, operasional konkrit, dan operasional formal.

Menurut Ibda (2015) dalam hasil penelitiannya mengenai teori Piaget, tingkatan perkembangan intelektual manusia mempengaruhi kedewasaan, pengalaman fisik, pengalaman logika, transmisi sosial dan pengaturan sendiri. Teori Piaget jelas sangat relevan dalam proses perkembangan kognitif anak, karena dengan menggunakan teori ini, manusia dapat mengetahui adanya tahap-tahap perkembangan tertentu pada kemampuan berpikir anak di levelnya. Susana dalam Sutrisno (2019) menyatakan bahwa siswa dikatakan menguasai sebuah konsep apabila siswa tersebut telah mampu melakukan serangkai proses yang disebut dengan proses kognitif meliputi kemampuan $\mathrm{C} 1$ menghafal (remember), C2 memahami (understand), C3 menerapkan (apply), $\mathrm{C} 4$ menganalisis (analyse), C5 mengevaluasi (evaluate), dan C6 membuat (create).

Sesuai paparan di awal, keterampilan berpikir kreatif merupakan bagian dari 4C, yaitu Creative Thinking Skills. Keterampilan berpikir kreatif menurut Liliawati (2011) adalah keterampilan kognitif untuk memunculkan dan mengembangkan gagasan maupun ide baru, sebagai pengembangan ide yang telah lahir sebelumnya, serta mampu memecahkan masalah berbagai sudut pandang. Munandar dalam Putra (2016) menyatakan bahwa karakteristik berpikir kreatif terdiri dari 4 aspek, yaitu fluency (kelancaran), flexibility (keluwesan), originality (keaslian), dan elaboration (keterincian) dalam berpikir.

Liliawati (2011) dalam penelitiannya menjabarkan keempat aspek keterampilan berpikir kreatif, anatara lain Fluency (menjawab dengan sejumlah jawaban jika ada pertanyaan, lancar mengungkapkan gagasangagasannya, dan dapat dengan cepat melihat kesalahan dan kelemahan dari suatu objek atau situasi) ; Flexibility (memberikan bermacammacam penafsiran terhadap suatu gambar, cerita, atau masalah, jika diberi suatu masalah biasanya memikirkan bermacam cara yang berbeda untuk menyelesaikannya, dan menggolongkan hal-hal menurut pembagian (kategori) yang berbeda) ; Originality (setelah membaca atau mendengar gagasan-gagasan, bekerja untuk menyelesaikan yang baru); dan Elaboration (mencari arti yang lebih mendalam terhadap jawaban atau pemecahan masalah dengan melakukan langkah langkah yang terperinci, mengembangkan atau memperkaya gagasan orang lain, mencoba detail-detail untuk melihat arah yang akan ditempuh).

Pada berbagai penelitian pendahulu, para peneliti menggunakan gender sebagai parameter tinjauan penelitian terhadap hasil pembelajaran, antara lain hasil penelitian Pambudiono (2013) menyatakan bahwa tidak ada perbedaan kemampuan berpikir siswa berdasarkan gender dengan penerapan strategi pembelajaran Jigsaw, akan tetapi mempengaruhi hasil belajar biologi siswa. Lain halnya dengan hasil penelitian Sulistiyawati (2017) yang menyatakan bahwa tidak terdapat perbedaan yang signifikan perlakuan pengaturan kelompok belajar berdasarkan gender terhadap kemampuan berpikir dan hasil belajar siswa. Hal ini didukung pula dengan penelitian Syarifah (2016), yaitu antara interaksi strategi pembelajaran dengan perbedaan jenis kelamin tidak berpengaruh terhadap keterampilan metakognitif siswa, meskipun hasil belajaranya tinggi yang perempuan, serta Himmah (2018) yang 
menunjukkan bahwa model Remap $R T$ berpengaruh terhadap keterampilan berpikir kreatif, sedangkan gender tidak berpengaruh secara signifikan.

UNESCO menjelaskan bahwa isu kesetaraan gender merupakan salah satu dari tujuan pembangunan berkelanjutan sejak era Millennium Development Goals (MDG's) hingga kini telah berganti menjadi Sustainable Development Goals (SDG's), yaitu mencapai kesetaraan gender dan pemberdayaan perempuan (termasuk akses yang setara ke pendidikan dasar antara anak perempuan dan anak laki-laki), perempuan dan anak perempuan yang terus menderita diskriminasi dan kekerasan di setiap bagian dunia. Kesetaraan gender bukan hanya hak asasi manusia yang mendasar, tetapi juga merupakan fondasi yang diperlukan untuk dunia yang damai, sejahtera, dan berkelanjutan.

Akses yang setara pada pendidikan dasar antara anak perempuan dan anak laki-laki dapat membantu pula dalam mencapai tujuan pembangunan berkelanjutan yang lainnya, seperti pendidikan yang berkualitas. Memperoleh pendidikan yang berkualitas adalah fondasi untuk menciptakan pembangunan berkelanjutan. Selain meningkatkan kualitas hidup, akses ke pendidikan inklusif dapat membantu membekali penduduk setempat dengan alat yang dibutuhkan untuk mengembangkan solusi inovatif untuk masalah terbesar dunia.

Berdasarkan pemaparan latar belakang tersebut, maka penelitian ini bertujuan untuk mengetahui pola kemampuan koginitif dan keterampilan berpikir kreatif pada konsep perubahan lingkungan antara siswa laki-laki dan perempuan di SMA Negeri 2 Mranggen.

\section{Metode Penelitian}

Penelitian ini merupakan penelitian pendahuluan dan non eksperimen, karena bertujuan untuk meneliti yang telah dimiliki oleh subjek penelitian secara wajar tanpa adanya usaha sengaja untuk memberikan perlakuan demi memunculkan variabel yang ingin diteliti. Populasi penelitian adalah siswa kelas XI yang terdiri dari 9 kelas di SMA Negeri 2 Mranggen. Teknik sampling menggunakan stratified proportional random sampling, yaitu mengambil sampel siswa secara acak dan menggunakan rumus Slovin dengan taraf signifikan 10\%, sehingga diperoleh 76 siswa dari 324 siswa. Jumlah 76 siswa tersebut kemudian dibagi menjadi 2 , masing-masing sama 38 siswa untuk laki-laki dan perempuan. Teknik pengumpulan data dalam penelitian ini berupa tes kemampuan koginitf dan keterampilan berpikir kreatif dalam bentuk soal pilihan ganda dan uraian pada materi perubahan lingkungan. Instrument yang digunakan berupa soal pilihan ganda yang memuat C1-C6 untuk kemampuan kognitif dan aspek berpikir kreatif untuk soal uraian. Data yang terkumpul kemudian dianalisis menggunakan anlisis deskriptif kuantitatif dan t-test independent, dengan taraf signifikansi 0,05 .

\section{Hasil Penelitian dan Pembahasan}

\section{Kemampuan Kognitif}

Tes kemampuan koginitif menggunakan tes pilihan ganda yang terdiri dari 20 soal dan secara acak termuat indikator kognitif berdasarkan taksonomi bloom C1-C6, yaitu mengingat $(\mathrm{C} 1)$, memahami $(\mathrm{C} 2)$, menerapkan (C3), menganalisis (C4), mengevaluasi (C5), mencipta (C6) dengaan masing-masing skor 5. Tes kemampuan kognitif diberikan kepada 76 orang siswa dengan rincian 38 siswa laki-laki dan 38 siswa perempuan. Frekuensi nilai dari 76 siswa yang mengerjakan soal untuk hasil tes kemampuan kognitif dapat dilihat pada Tabel 1 seperti berikut.

\begin{tabular}{cc}
$\begin{array}{c}\text { Tabel 1. Frekuensi nilai kemampuan kognitif siswa SMA } \\
\text { Negeri 2 Mranggen }\end{array}$ \\
\hline Nilai & Frekuensi \\
\hline 0 & 2 \\
5 & 3 \\
10 & 6 \\
15 & 2 \\
20 & 6 \\
25 & 16 \\
30 & 8 \\
35 & 10 \\
40 & 12 \\
45 & 6 \\
50 & 4 \\
55 & 1 \\
Jumlah & 76 \\
\hline
\end{tabular}

Berdasarkan Tabel 1, dapat diketahui bahwa frekuensi terbanyak adalah 16 siswa mendapatkan nilai 25, kemudian 12 siswa mendapatkan nilai 40, dan 10 siswa mendapatkan nilai 35 . Sementara itu, nilai tertinggi adalah 55 yang hanya didapatkan oleh 1 siswa, sedangkan nilai terendah adalah 0 yang 
didapatkan oleh 2 siswa. Nilai yang lainnya, seperti nilai 5 oleh 3 siswa, nilai 10 oleh 6 siswa, nilai 15 oleh 2 siswa, nilai 20 oleh 6 siswa, nilai 30 oleh 8 siswa, nilai 45 oleh 6 siswa, dan nilai 50 oleh 4 siswa. Data pada tabel 1 dapat dilihat dengan jelas perbedaannya pada grafik berikut.

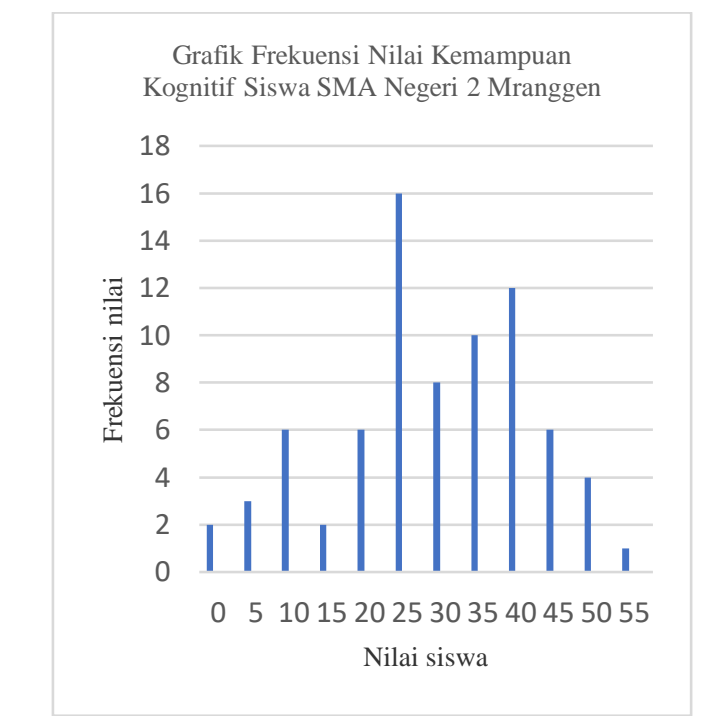

Gambar 1. Grafik Frekuensi Nilai Kemampuan Kognitif Siswa SMA Negeri 2 Mranggen

Adapun hasil tes kemampuan kognitif untuk setiap indikator dapat dilihat pada Tabel 2 berikut.

Tabel 2. Perhitungan kemampuan kognitif siswa di SMA Negeri

\begin{tabular}{ccccc} 
& \multicolumn{3}{c}{ 2 Mranggen } \\
\hline Indikator & $\begin{array}{c}\text { Jumla } \\
\mathbf{h} \\
\text { Soal }\end{array}$ & $\begin{array}{c}\text { Jumla } \\
\mathbf{h} \\
\text { nilai }\end{array}$ & $\begin{array}{c}\text { Rata- } \\
\text { rat } \\
\mathbf{a}\end{array}$ & $\begin{array}{c}\text { Persentas } \\
\mathbf{e}\end{array}$ \\
\hline $\begin{array}{c}\text { Mengingat } \\
\text { (C1) } \\
\text { Memahami } \\
\text { (C2) }\end{array}$ & 2 & 140 & 1.84 & $2.42 \%$ \\
$\begin{array}{c}\text { Menerapkan } \\
\text { (C3) }\end{array}$ & 2 & 175 & 2.30 & $3.03 \%$ \\
$\begin{array}{c}\text { Menganalisis } \\
\text { (C4) }\end{array}$ & 6 & 625 & 8.22 & $10.82 \%$ \\
$\begin{array}{c}\text { Mengevaluas } \\
\text { i (C5) }\end{array}$ & 4 & 320 & 4.21 & $5.54 \%$ \\
$\begin{array}{c}\text { Mencipta } \\
\text { (C6) }\end{array}$ & 4 & 630 & 8.29 & $10.91 \%$ \\
Jumlah & 20 & 2220 & 29.2 & $38.42 \%$ \\
\hline
\end{tabular}

Berdasarkan data pada Tabel 2 didapatkan rata-rata nilai sebesar 29.2 atau sebesar $38.42 \%$, dengan rincian kemampuan C1 $2.42 \%, \mathrm{C} 23.03 \%, \mathrm{C} 35.71 \%, \mathrm{C} 410.82 \%$, C5 $5.54 \%$, dan C6 $10.91 \%$. Kemudian, data hasil kemampuan kognitif dapat dibedakan kembali menjadi dua golongan, yaitu laki-laki dan perempuan seperti pada Tabel 3 dan 4 berikut.

\begin{tabular}{ccccc}
\multicolumn{5}{c}{ Tabel 3. Perhitungan kemampuan kognitif siswa laki-laki di } \\
SMA Negeri 2 Mranggen \\
\hline $\begin{array}{c}\text { Jumla } \\
\text { h } \\
\text { Indikator } \\
\text { Soal }\end{array}$ & $\begin{array}{c}\text { Jumla } \\
\text { hilai }\end{array}$ & $\begin{array}{c}\text { Rata } \\
\text { ra } \\
\text { ta }\end{array}$ & Persentase \\
\hline $\begin{array}{c}\text { Mengingat } \\
\text { (C1) }\end{array}$ & 2 & 55 & 1.45 & $3.82 \%$ \\
$\begin{array}{c}\text { Memahami } \\
\text { (C2) }\end{array}$ & 2 & 90 & 2.37 & $6.24 \%$ \\
$\begin{array}{c}\text { Menerapkan } \\
\text { (C3) }\end{array}$ & 2 & 150 & 3.95 & $10.39 \%$ \\
$\begin{array}{c}\text { Menganalisis } \\
\text { (C4) }\end{array}$ & 6 & 280 & 7.37 & $19.39 \%$ \\
$\begin{array}{c}\text { Mengevaluasi } \\
\text { (C5) }\end{array}$ & 4 & 130 & 3.42 & $9.00 \%$ \\
$\begin{array}{c}\text { Mencipta } \\
\text { (C6) }\end{array}$ & 4 & 345 & 9.08 & $23.89 \%$ \\
$\begin{array}{c}\text { Jumlah } \\
\text { (C) }\end{array}$ & 20 & 1050 & 27.6 & $72.74 \%$ \\
\hline
\end{tabular}

Tabel 4. Perhitungan kemampuan kognitif siswa perempuan di SMA Negeri 2 Mranggen

\begin{tabular}{ccccc}
\hline Indikator & $\begin{array}{c}\text { Jumla } \\
\mathbf{h} \\
\text { Soal }\end{array}$ & $\begin{array}{c}\text { Jumla } \\
\mathbf{h} \\
\text { nilai }\end{array}$ & $\begin{array}{c}\text { Rata- } \\
\text { rat } \\
\mathbf{a}\end{array}$ & $\begin{array}{c}\text { Persentas } \\
\mathbf{e}\end{array}$ \\
\hline $\begin{array}{c}\text { Mengingat } \\
\text { (C1) }\end{array}$ & 2 & 85 & 2.24 & $5.89 \%$ \\
\hline $\begin{array}{c}\text { Memahami } \\
\text { (C2) }\end{array}$ & 2 & 85 & 2.24 & $5.89 \%$ \\
\hline $\begin{array}{c}\text { Menerapkan } \\
\text { (C3) }\end{array}$ & 2 & 180 & 4.74 & $12.47 \%$ \\
\hline $\begin{array}{c}\text { Menganalisis } \\
\text { (C4) }\end{array}$ & 6 & 345 & 9.08 & $23.89 \%$ \\
\hline $\begin{array}{c}\text { Mengevaluas } \\
\text { i (C5) }\end{array}$ & 4 & 190 & 5.00 & $13.16 \%$ \\
\hline $\begin{array}{c}\text { Mencipta } \\
\text { (C6) }\end{array}$ & 4 & 285 & 7.50 & $19.74 \%$ \\
\hline Jumlah & 20 & 1170 & 30.79 & $81.05 \%$ \\
\hline
\end{tabular}

Berdasarkan Tabel 3 dan 4 diperoleh analisis data siswa laki-laki dan perempuan, bahwa kemampuan kognitif siswa laki-laki memiliki nilai rata-rata 27.63 atau $72.74 \%$ < $81.05 \%$ pada siswa perempuan dengan nilai rata-rata 30.79 . Kemampuan $\mathrm{C} 1$ siswa laki-laki $3.82 \%<5.89 \%$ pada siswa perempuan, $\mathrm{C} 2$ siswa laki-laki $6.24 \%>5.89 \%$ dari siswa perempuan, C3 siswa laki-laki $10.39 \%<12.47$ $\%$ pada siswa perempuan, C4 siswa laki-laki $19.39 \%<28.89 \%$ pada siswa perempuan, C5 siswa laki-laki $9.00 \%<13.16 \%$ pada siswa perempuan, dan C6 siswa laki-laki $23.89 \%>$ $19.74 \%$ dari siswa perempuan. Kemampuan kognitif siswa laki-laki dan perempuan jika dibandingkan dari setiap indikator menunjukkan bahwa kemampuan kognitif siswa perempuan lebih tinggi dari siswa lakilaki. Grafik perbedaan kemampuan kognitif 
siswa laki-laki dan perempuan pada masingmasing indikator sebagai berikut.

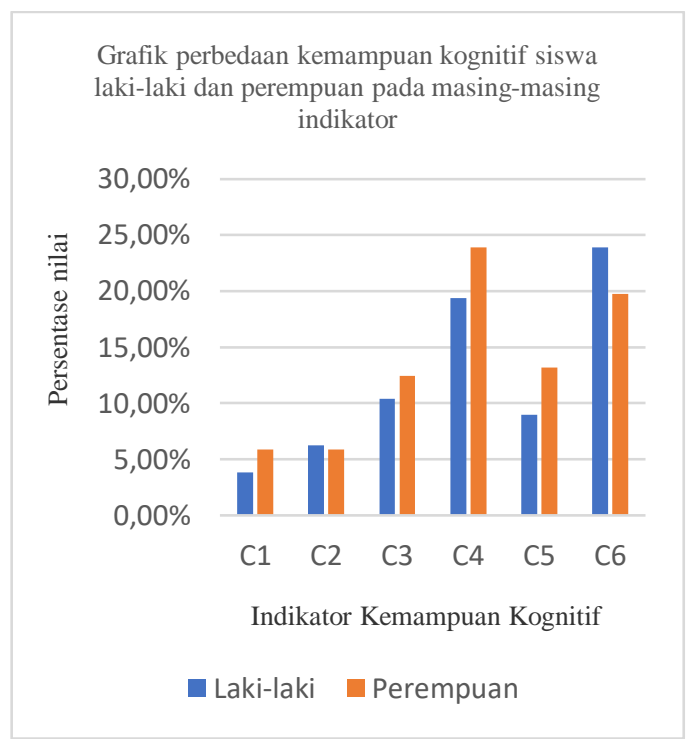

Gambar 2. Grafik perbedaan kemampuan kognitif siswa lakilaki dan perempuan pada masing-masing indikator

Selanjutnya, data yang diperoleh dari kemampuan kognitif siswa laki-laki dan perempuan diuji menggunakan t-test independent. Berdasarkan hasil uji t-test independent diperoleh bahwa t-hitung sebesar 1,067 dan t-tabel dengan signifikanasi $(\alpha)$ 5\% sebesar 1,922. Hasil perhitungan menunjukkan bahwa $\mathrm{H} 0$ gagal ditolak yang berarti tidak ada perbedaan nyata antara kemampuan kognitif siswa laki-laki dengan siswa perempuan.

Meninjau dari hasil penelitian kemampuan kognitif tersebut, maka perbedaan gender tidak mempengaruhi kemampuan kognitif siswa laki-laki dengan perempuan. Hasil tersebut, sejalan dengan penelitian Avila (2017) ; Habibah (2015) ; Yuliskurniawati (2018) ; dan Sulistyono (2017) yang masingmasing hasil penelitian menyatakan bahwa tidak ada pengaruh gender terhadap hasil kemampuan kognitif siswa.

\section{Keterampilan Berpikir Kreatif}

Tes keterampilan berpikir kreatif siswa menggunakan tes essay yang terdiri dari 4 soal, masing-masing soal mewakili satu indikator kemampuan berpikir kreatif, yaitu berpikir lancar (fluency), berpikir luwes (flexibility), berpikir orisinil (originality) dan berpikir terperinci (elaboration) dengan masing- masing skor maksimal 25. Frekuensi nilai dari 76 siswa yang mengerjakan soal untuk hasil tes keterampilan berpikir kreatif dapat dilihat pada Tabel 5 berikut.

Tabel 5. Frekuensi nilai keterampilan berpikir kreatif siswa SMA Negeri 2 Mranggen

\begin{tabular}{cc} 
Nilai & Frekuensi \\
\hline 15 & 1 \\
20 & 2 \\
30 & 5 \\
40 & 7 \\
50 & 14 \\
60 & 17 \\
70 & 19 \\
80 & 5 \\
90 & 5 \\
100 & 1 \\
Jumlah & 76
\end{tabular}

Berdasarkan Tabel 5, dapat diketahui bahwa frekuensi terbanyak adalah 19 siswa mendapatkan nilai 70, kemudian 17 siswa mendapatkan nilai 60, dan 14 siswa mendapatkan nilai 50. Sementara itu, nilai tertinggi adalah 100 yang hanya didapatkan oleh 1 siswa, sedangkan nilai terendah adalah 15 yang didapatkan oleh 1 siswa. Nilai yang lainnya, seperti nilai 20 oleh 2 siswa, nilai 30 oleh 5 siswa, nilai 40 oleh 7 siswa, nilai 80 oleh 5 siswa, dan nilai 90 oleh 5 siswa. Data pada Tabel 5 dapat dilihat dengan jelas perbedaannya pada grafik berikut.

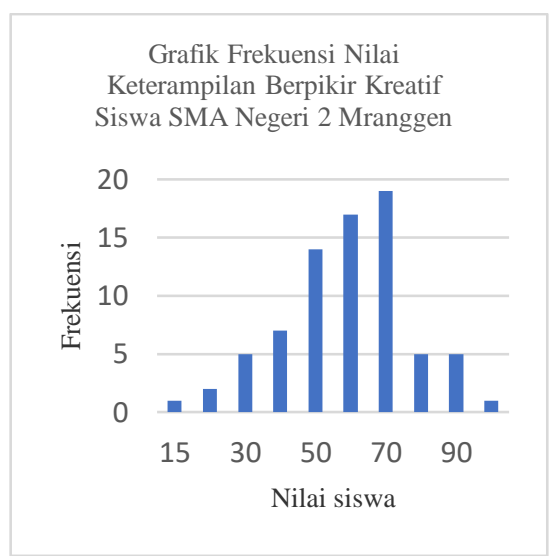

Gambar 3. Grafik Frekuensi Nilai Keterampilan Berpikir Kreatif Siswa SMA Negeri 2 Mranggen

Adapun hasil tes keterampilan berpikir kreatif untuk setiap indikator dapat dilihat pada Tabel 6 berikut.

Tabel 6. Perhitungan keterampilan berpikir kreatif siswa di SMA Negeri 2 Mranggen 


\begin{tabular}{cccc}
\hline Indikator & $\begin{array}{c}\text { Jumlah } \\
\text { Nilai }\end{array}$ & $\begin{array}{c}\text { Rata- } \\
\text { rata }\end{array}$ & Persentase \\
\hline Fluency & 1350 & 17.76 & $23.37 \%$ \\
Flexibility & 1000 & 13.16 & $17.32 \%$ \\
Originality & 985 & 12.96 & $17.05 \%$ \\
Elaboration & 1150 & 15.13 & $19.91 \%$ \\
Rata-rata keterampilan & 59.01 & $77.65 \%$ \\
berpikir kreatif & & \\
\hline
\end{tabular}

Berdasarkan data pada Tabel 6 dapat diketahui bahwa keterampilan berpikir kreatif siswa memiliki rata-rata 59.01 atau $77.65 \%$ dengan rincian, keterampilan Fluency $23.37 \%$, Flexibility $17.32 \%$, Originality $17.05 \%$, dan Elaboration $19.91 \%$. Persentase sebesar 77.65 $\%$ tersebut menunjukkan bahwa keterampilan berpikir kreatif siswa dalam kategori kreatif. Kemudian, data hasil keterampilan berpikir kreatif tersebut dapat dibedakan kembali menjadi dua golongan, yaitu laki-laki dan perempuan seperti pada Tabel 7 dan 8 berikut.

\begin{tabular}{cccc}
\multicolumn{4}{c}{ Tabel 7. Perhitungan keterampilan berpikir kreatif siswa } \\
laki-laki di SMA Negeri 2 Mranggen \\
\hline Indikator & Jumlah & Rata-rata & Persentase \\
& Nilai & & \\
\hline Fluency & 620 & 16.32 & $42.95 \%$ \\
Flexibility & 470 & 12.37 & $32.55 \%$ \\
Originality & 455 & 11.97 & $31.50 \%$ \\
Elaboration & 470 & 12.37 & $32.55 \%$ \\
\hline
\end{tabular}

Tabel 8. Perhitungan keterampilan berpikir kreatif siswa perempuan di SMA Negeri 2 Mranggen

\begin{tabular}{|c|c|c|c|}
\hline Indikator & $\begin{array}{r}\text { Jumlah } \\
\text { Nilai }\end{array}$ & Rata-rata & Persentase \\
\hline Fluency & 730 & 19.21 & $50.55 \%$ \\
\hline Flexibility & 530 & 13.95 & $36.71 \%$ \\
\hline Originality & 530 & 13.95 & $36.71 \%$ \\
\hline Elaboration & 680 & 17.89 & $47.08 \%$ \\
\hline
\end{tabular}

Tabel 7 dan 8 merupakan data perhitungan keterampilan berpikir kreatif siswa laki-laki dan perempuan. Berdasarkan kedua tabel tersebut, dapat diketahui bahwa keterampilan Fluency siswa laki-laki $42.95 \%$ < $50.55 \%$ pada siswa perempuan, Flexibility siswa laki-laki $32.55 \%<36.71 \%$ pada siswa perempuan, Originality siswa laki-laki $31.50 \%$ $<36.71 \%$ pada siswa perempuan, dan Elaboration $32.55 \%<47.08 \%$. Keterampilan berpikir kreatif siswa laki-laki dan perempuan jika dibandingkan dari setiap indikator menunjukkan bahwa keterampilan berpikir kreatif siswa perempuan lebih tinggi dari siswa laki-laki. Grafik perbedaan keterampilan berpikir kreatif siswa laki-laki dan perempuan pada masing-masing indikator sebagai berikut.

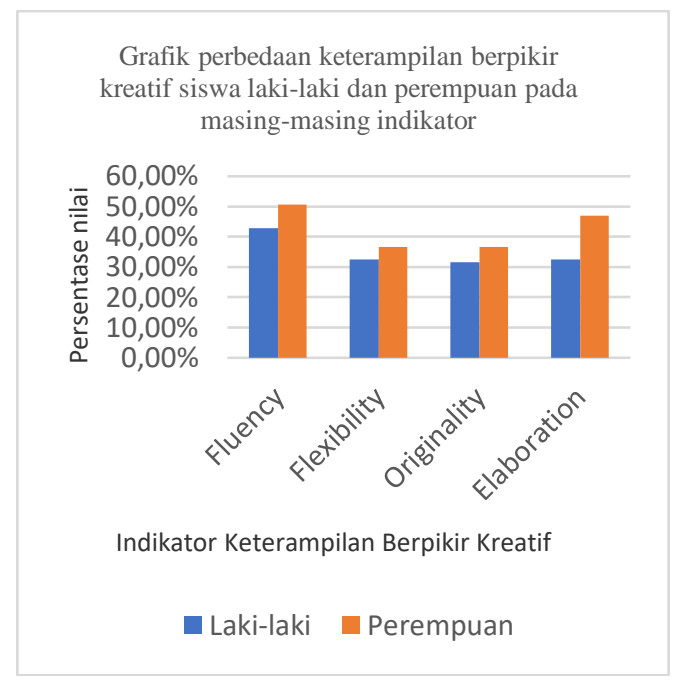

Gambar 4. Grafik perbedaan keterampilan berpikir kreatif siswa laki-laki dan perempuan pada masing-masing indikator

Selanjutnya, data yang diperoleh dari keterampilan berpikir kreatif siswa laki-laki dan perempuan diuji menggunakan t-test independent. Berdasarkan hasil uji t-test independent diperoleh bahwa t-hitung sebesar 3,088 dan t-tabel dengan signifikanasi $(\alpha)$ 5\% sebesar 1,922. Hasil perhitungan menunjukkan bahwa H0 gagal ditolak yang berarti tidak ada perbedaan nyata antara keterampilan berpikir kreatif siswa laki-laki dengan siswa perempuan.

Hasil temuan pada studi pendahuluan ini adalah tidak ada perbedaan yang nyata pada keterampilan berpikir kreatif antara siswa lakilaki dengan perempuan. Hal ini selaras dengan penelitian yang relevan dan sudah pernah dilakukan sebelumnya, seperti Ulfa (2018) ; Abraham (2016) ; Suprapto (2018) ; dan Sulistyono (2017) pada hasil keempat penelitian tersebut menyatakan bahwa kemampuan berpikir kreatif antara siswa lakilaki dengan perempuan menunjukkan tidak terdapat perbedaan secara signifikan, sehingga perbedaan gender tidak mempengaruhi pada hasil keterampilan berpikir kreatif siswa.

Selain pada kemampuan kognitif dan keterampilan berpikir kreatif, faktor gender dinilai pula tidak memberikan pengaruh terhadap kemampuan dan kesadaran metakognitif pada penelitian Darmawan (2018) ; Soraya (2010) ; dan Habibah (2015). Meskipun demikian, adapula hasil penelitian mengenai kemampuan kogntif maupun keterampilan berpikir kreatif yang tidak sejalan 
dengan hasil penelitian ini, antara lain penelitian Rosa (2017) dan Lestari (2016) yang menyatakan bahwa kemampuan kognitif siswa perempuan lebih tinggi dibanding laki-laki, serta hasil penelitian Sipayung (2017) yang menyatakan bahwa kemampuan kognitif lakilaki lebih tinggi dibanding perempuan.

\section{Paradigma Gender bagi Pendidikan}

Laporan dari UNESCO berkaitan dengan Sustainable Development Goals (SDG's) pada pendidikan yang berkualitas dan kesetaraan gender menunjukkan bahwa dalam dekade terakhir, kemajuan besar telah dicapai untuk meningkatkan akses pendidikan di semua tingkatan dan meningkatkan angka partisipasi di sekolah, terutama untuk perempuan dan anak perempuan. Keahlian literasi dasar telah meningkat pesat, namun upaya yang lebih besar diperlukan untuk membuat langkah lebih besar pula guna mencapai tujuan pendidikan universal. Sebagai contoh, dunia telah mencapai kesetaraan dalam pendidikan dasar antara anak perempuan dan anak laki-laki, tetapi beberapa negara telah mencapai target di semua tingkat pendidikan.

UNESCO telah membuat kebijakan "Education for Air" dan seluruh anggota menyepakati, suatu kebijakan untuk dihapusnya disparitas gender pada pendidikan dasar hingga menengah menjelang tahun 2005, dan mencapai kesetaraan pendidikan menjelang tahun 2015 sebagai strategi untuk menghapuskan kesenjangan gender (Wahyuningsih, et al., 2009).

UNESCO memaparkan lebih lanjut untuk dapat memperbaiki masalah kesetaraan gender, seperti untuk para peremuan dapat tetap bersekolah, membantu memberdayakan teman perempuan untuk melakukan hal yang sama dan memperjuangkan hak untuk mengakses layanan kesehatan seksual dan reproduksi. Sementara itu, untuk laki-laki dapat bekerja bersama perempuan dan anak perempuan untuk mencapai kesetaraan gender dan merangkul hubungan yang sehat dan saling menghormati, mendanai sosialisasi pendidikan untuk mengekang praktik budaya seperti mutilasi alat kelamin wanita dan mengubah undang-undang berbahaya yang membatasi hak-hak perempuan dan anak perempuan dan mencegah mereka mencapai potensi penuh mereka.
Zaduqisti (2009) pada karyanya telah merangkum faktor-faktor yang membuat timbulnya paradigma dari berbagai pandangan terkait pelabelan antara laki-laki dan perempuan, antara lain 1) Biologis, adanya perbedaan genetik, biokimia, dan anatomi antar jenis kelamin, namun tidak terlalu menentukan perilaku dan sikap gender, melainkan justru factor social dan kognitif strereotipe bisa tumbuh ; 2) Sosial, adanya teori psikoanalitik gender dan kognisi sosial gender yang menyatakan bahwa stereotype peran gender dipengaruhi oleh pengalaman social ; dan 3) Kognitif, faktor kognitif dinilai mendominasi stereotype peran gender.

Pada teori skema gender oleh Santrock (2017) dikatakan bahwa jenis kelamin merupakan teori kognitif yang paling banyak diterima. Ketika anak-anak secara bertahap mengembangkan skema gender, mencari tahu apa gender yang tepat, dan gender yang tidak pantas dalam budaya mereka, saat itulah stereotip gender muncul. Struktur kognitif, jaringan asosiasi yang memandu persepsi individu dan mengatur dunia mengenai perempuan dan laki-laki adalah hal yang disebut sebagai skema gender.

Lebih lanjutnya Santrock menyatakan bahwa evolusi, keturunan, dan pengalaman sosial merupakan faktor yang menjadikan adanya persamaan dan perbedaan antara otak laki-laki dan perempuan. Selain itu, dikatakan pada kemampuan intelektual tidak ada peran gender, akan tetapi muncul pada beberapa ranah kognitif, seperti matematika dan kemampuan verbal. Dikatakan bahwa keterampilan visual-spasial anak laki-laki lebih baik dibandingkan perempuan dan sedikit lebih baik dalam sains dibandingkan anak perempuan di kelas 4, 8, dan 12 (Santrock, 2017).

Berdasarkan hasil temuan langsung di lapangan yang menghasilkan bahwa tidak ada keterkaitan gender dengan hasil kognitif maupun kreatif, serta didukung dengan penelitian yang relevan, maka dapat menjadi masukan dalam pengembangan proses pembelajaran untuk tidak membedakan antara laki-laki dan perempuan. Hal ini dapat sekaligus menunjang keberhasilan tujuan pembangunan berkelanjutan dari tujuan kesetaraan gender, pendidikan yang berkualitas, maupun yang lainnya. 


\section{Kesimpulan dan Rekomendasi}

Hasil penelitian menunjukkan rata-rata persentase kemampuan kognitif siswa sebesar $38.42 \%$, rata-rata siswa laki-laki $72.74 \%$, dan perempuan $81.05 \%$. Sementara itu, hasil ratarata persentase keterampilan berpikir kreatif siswa sebesar $77.65 \%$. Adapun hasil uji beda $t$ test independent kemampuan kognitif dan keterampilan berpikir kreatif antara siswa lakilaki dengan perempuan diperoleh bahwa thitung sebesar -1,067 dan t-tabel dengan signifikanasi $(\alpha) \quad 5 \%$ sebesar 1,922 untuk kemampuan kognitif. Sementara itu, keterampilan berpikir kreatif diperoleh bahwa t-hitung sebesar $-3,088$ dan t-tabel dengan signifikanasi $(\alpha) \quad 5 \%$ sebesar 1,922. Hasil perhitungan keduanya menunjukkan bahwa $\mathrm{H} 0$ gagal ditolak yang berarti tidak ada perbedaan nyata antara keterampilan berpikir kreatif siswa laki-laki dengan siswa perempuan.

Berdasarkan hasil dan pembahasan penelitian, rekomendasi yang disampaikan adalah perlu penelitian lebih lanjut mengenai kemampuan kognitif dan keterampilan berpikir kreatif siswa ditinjau dari faktor gender guna menunjang keberhasilan tujuan pembangunan berkelanjutan khusus pada tujuan kesetaraan gender.

\section{Daftar Pustaka}

Abraham, A. (2016). Gender and creativity: an overview of psychological and neuroscientific literature. Brain imaging and behavior, 10(2), 609-618.

Avila, S., Mahanal, S., \& Zubaidah, S. (2018). Pengaruh Model Pembelajaran Biologi Berbasis Reading-Concept Map-Cooperative Script Dan Gender Terhadap Hasil Belajar Kognitif Siswa Kelas X SMA Negeri 2 Malang. In Seminar Nasional Pendidikan IPA 2017 (Vol. 2).

Darmawan, E., Brasilita, Y., Zubaidah, S., \& Saptasari, M. (2018). Enhancing metacognitive skills of students with different gender using simas eric learning model at state senior high school 6 Malang. Biosfer, 11(1), 48-57.

Goal 5: Achieve gender equality and empower all women and girls. Diakses pada 15 Januari 2020, dari https://www.un.org/.

Griffin, P., McGaw, B., \& Care, E. (2018). Assessment and Teaching of 21st Skills. New York: Springer Publishing Company.

Habibah, K. N. (2015). Pengaruh gender terhadap keterampilan metakognitif dan hasil belajar kognitif biologi pada penerapan strategi pembelajaran pbmp (pemberdayaan berpikir melalui pertanyaan) dipadu tps (think pair share) pada siswa kelas xi ipa di malang. Disertasi dan tesis program pascasarjana um.

Himmah, S. F., Mahanal, S., \& Zubaidah, S. (2018, February). Pengaruh Model Pembelajaran Biologi Berbasis Reading-Concept MapReciprocal Teaching Dan Gender Terhadap Keterampilan Berpikir Kreatif Siswa Kelas $\mathrm{X}$ SMA Negeri 7 Malang. In Seminar Nasional Pendidikan IPA 2017 (Vol. 2).

Ibda, F. (2015). Perkembangan kognitif: teori jean piaget. Intelektualita, 3(1).

Lestari, N. T. (2016). Analisis Kemampuan Kognitif, Menalar dan Sikap Siswa SMP pada Materi Ekosistem Dikaitkan dengan Gender.

Liliawati, M. W. (2011). Pembekalan Keterampilan Berpikir Kreatif Siswa SMA Melalui Pembelajaran Fisika Berbasis Masalah. Jurnal Pengajaran MIPA, 16(2), 93-98.

Pambudiono, A., Zubaidah, S., \& Mahanal, S. (2013). Perbedaan kemampuan berpikir dan hasil belajar biologi siswa kelas $\mathrm{x}$ sma negeri 7 malang berdasarkan jender dengan penerapan strategi jigsaw. Laporan Penelitian. Universitas Malang (e-journal. um. ac. id).

Putra, R. D. (2016). Peningkatan Kemampuan Berpikir Kreatif Siswa melalui Model Pembelajaran Inkuiri Terbimbing pada Siswa Kelas XI MIA 1 SMA Negeri Colomadu Karanganyar Tahun Pelajaran 2015/2016 (Doctoral dissertation, Universitas Sebelas Maret).

Quality Education. Diakses pada 15 Januari 2020, dari https://www.un.org/.

Rosa, F. O. (2017). Eksplorasi Kemampuan Kognitif Siswa Terhadap Kemampuan Memprediksi, Mengobservasi dan Menjelaskan Ditinjau Dari Gender. Jurnal Pendidikan Fisika, 5(2), 111-118.

Santrock, J. W. (2017). Educational psychology: theory and application to fitness and performance, sixth edition. McGraw-Hill Education

Sipayung, H. D., Sihombing, E., \& Sani, R. A. (2017). Penerapan model pembelajaran berbasis masalah berdasarkan gender terhadap kognitif tingkat tinggi siswa.

Soraya, R. (2010). Pengaruh penerapan strategi pembelajaran (PBMP+ TPS dan inkuiri) dan jenis kelamin terhadap hasil belajar dan keterampilan metakognitif siswa sekolah dasar (Doctoral dissertation, Universitas Negeri Malang). 
Sulistiyawati, S., \& Andriani, C. (2017). Kemampuan berpikir kritis dan hasil belajar biologi berdasarkan perbedaan gender siswa. Wacana Akademika: Majalah Ilmiah Kependidikan, 1(2).

Sulistiyono, E. (2017). Pengaruh Metode Speed Reading dipadu dengan Metode Mind Mapping dan Gender terhadap Peningkatan Keterampilan Berpikir Kreatif dan Hasil Belajar Kognitif Biologi Siswa Kelas X di SMA Swasta Kota Surabaya. Disertasi dan Tesis Program Pascasarjana UM.

Suprapto, S., Zubaidah, S., \& Corebima, A. D. (2018). Pengaruh Gender terhadap Keterampilan Berpikir Kreatif Siswa pada Pembelajaran Biologi. Jurnal Pendidikan: Teori, Penelitian, dan Pengembangan, 3(3), 325-329.

Sutrisno, A., Mila, H., \& Santoso, S. (2019, October). Perbedaan Kemampuan Kognitif Siswa dengan Menggunakan Model Problem Based Learning (PBL), Project Based Learning (PjBL) dan Inkuiri Di SMP Negeri 24 Bengkulu Utara. In Seminar Nasional Sains \& Entrepreneurship (Vol. 1, No. 1).

Syarifah, H., Indriwati, S. E., \& Corebima, A. D. (2016). Pengaruh strategi pembelajaran reading questioning and answering (RQA) dipadu think pair share (TPS) terhadap keterampilan metakognitif siswa laki-laki dan perempuan SMAN di Kota Malang.
Jurnal Pendidikan: Teori, Penelitian, dan Pengembangan, 1(5), 801-805.

Ulfa, A., Ruzyati, M., Pujiastuti, P., San, S. M., \& Prayitno, B. A. Profil Kemampuan Berpikir Kreatif Siswa Laki-laki dan Perempuan di Sebuah SMA Negeri Surakarta. In Proceeding Biology Education Conference: Biology, Science, Enviromental, and Learning (Vol. 15, No. 1, pp. 532-540).

Wahyuningsih, R. D., Suharto, D. G., Nugraheni, I. D.A, Hidayat, R. S., Poerwandari, E. K. (2009). Pengembangan Model Pendidikan Adil Gender Pada Sekolah Dasar Untuk Optimalisasi Pengarustamaan Gender Bidang Pendidikan. LPPM UNS. Diakses pada 3 Januari 2020, dari https://lppm.uns.ac.id/id/

Yuliskurniawati, I. D. (2019). Pengaruh Model Pembelajaran RICOSRE berdasarkan Gender terhadap Keterampilan Proses Sains, dan Hasil Belajar Kognitif Biologi SMA Negeri di Malang. Disertasi dan Tesis Program Pascasarjana UM.

Zaduqisti, E. (2009). Stereotype Peran Gender bagi Pendidikan Anak. Jurnal Muwazah Vol, 1, 73-82.

Zubaidah, S. (2018). Mengenal 4c: Learning And Innovation Skills Untuk Menghadapi Era Revolusi Industri 4.0. Universitas Negeri Malang : Malang. 